\title{
ORHON YAZITLARINDA ARA EKLER
}

\author{
Arş. Gör. Aysel AHMEDOVA*
}

ÖZ: Bu yazıda Türk dillerinde yapım ve çekim ekleri arasındaki ilişki gözden geçirilecek ve bu ekler arasında ara ekler olarak isimlendirilecek olan başka bir ek grubunun da bulunduğu ileri sürülecektir. Burada ara ekler denildiğinde hem yapım hem de çekim eklerinin özelliklerine ve işlevine sahip eklerden söz edilecektir. Bu eklere isim soylu sözcüklerde $+k i,+l \breve{g},+s i z$ ve $+c ̧ a$ ekleri, fillerdeyse çatı ekleri dâhildir. Bu ekler yeni bir sözcük yapan ekler olarak görülmenin yanı sıra çekim ekleri olarak da nitelendiriliyor. Bu yazıda ara eklerin Orhon yazıtlarındaki durumu incelenecek, bu durum çağdaş Türk dilleriyle kıyaslanacak ve onların çağdaş Türk dillerindekinden farklı kullanım özellikleri üzerinde durulacaktır.

Anahtar Kelimeler: Türk dilleri, Eski Türkçe, yapım ekleri, çekim ekleri, fiil çatısı.

\section{Marginal Suffixes in Orkhon Inscriptions}

ABSTRACT: In this paper, the relationship between derivational and inflectional suffixes will be investigated and it will be suggested that there is another suffix group between these two groups which is called marginal suffixes. Here the term marginal suffixes are used to depict the suffixes with the properties and functions of both derivational and inflectional suffixes. These suffixes include $+k i,+l \ddot{\gamma},+s \ddot{z}$, and $+\check{c} a$ in nominal and the suffixes of voice in verbs. Besides being seen as the suffixes making new words, these suffixes are also qualified as inflectional suffixes. In this paper, the status of marginal suffixes in Orkhon Inscriptions will be analysed, this point will be compared to those in the modern Turkic languages, and their usage that is different from the one in modern Turkic languages will be specified.

Keywords: Turkic languages, Old Turkic, derivational suffixes, inflectional suffixes, verbal voice.

\footnotetext{
* Azerbaycan Milli İlimler Akad. Dilcilik Enst. aysel_009@mail.ru
} 


\section{Giriş}

Temel gramer kitaplarında ekler yapım ve çekim ekleri olmak üzere iki kısma ayrılır. Fakat eklerin bazıları bu iki gruba da has özellikler taşır. Son zamanlarda eklerin ikiden fazla türe ayrılması, eklerin derecelendirilmesi, yapım ve çekim ekleri arasında keskin bir fark olmadığı, iki türün kesişmesinde bulunan eklerin olduğu fikirleri ortaya çıkmıştır. Yapım ve çekim ekleri arasında yer alan ekler çeşitli terimlerle adlandırılmıştır: stilistik ekler (Ganiyev 2011: 641), şekil yapan ekler, yap1 ekleri, ara ekler (Başdaş 2011). Ara ekler bizce bu kavramı daha iyi anlatır. Bu ekler yalnız çağdaş Türkçede değil, en eski yazılı kaynaklarımızdan olan Orhon yazıtlarının dilinde de görülür. Bunlar çok işlevli (çok fonksiyonlu) ekler olarak da nitelendirilir (Ganiyev 2011: 641). Ancak çok fonksiyonlu ekler kullanıldığ1 yere göre yapım yahut çekim eki olabilir. Örneğin, isim-fiil ve sıfatfiil ekleri yerine göre fiilden isim ve sıfat yapan ekler olarak da kullanılır. Ara eklerse aynı sözcükte hem yapım hem de çekim eki özellikleri taşır.

Ara ekler bazen şekil yapan ekler olarak da görülür. Rusçada buna формаобразование, İngilizcede ise inherent inflection ad1 verilir. Ancak N. A. Baskakov şekil yapma terimine şüpheyle yaklaşır ve gösterir ki, sözcük değiştirme de şekil yapmadır. O sentaktik olmayan kategorilere (tarz, fiilin ad şekilleri, şekil, zaman) sözcük yapımı olarak bakar (Abdullina 2008: 5). M. Habiçev şekil yapan eklerin gövdeye dâhil olduğunu ve köke daha yakın olduğunu belirtir (Habiçev 1977: 5). Hâlbuki + ki eki köke daha uzaktır ve çekim eklerinden sonra gelir. Bu durumda $+k i$ şekil yapan ek olarak algılanamaz. M. Habiçev'in bu fikri fiil çatısı ekleri için de geçerli olabilir. K. A. Levkovskaya'ya göre, şekil yapan ekler sözün anlamına yeni bir şey katar ancak yapım eklerine nazaran daha soyuttur (Levkovskaya 1952: 162-163). Çekim ekleri şekil yapanlardan, onlarsa yapım eklerinden sonra gelir (Abdullina 2008: 8). Bu açıdan $+k i$ ne yapım eki ne de şekil yapan ek olarak davranır. Yani ona şekil yapan ek demek doğru değildir. Aslında şekil yapan eklerle ara ekler aynı değildir. Şekil yapan ekler de yapım ekleri gibi her köke eklenemez. Bu iki tarafın da anlam özellikleri ile ilgilidir. Şekil yapan ekler çok anlamlı ve çok fonksiyonlu olması ile seçilir. Çekim söz dizimiyle ilgilidir, söz dizimsel bağlılık ifade eder, şekil yapımı ise şekil bilgisine aittir, anlamsal bağlılık ifade eder (Abdullina 2008: 10).

Türk dillerinde yapım ve çekim ekleri arasında benzerlikler olduğu ile ilgili görüşler de var. Özellikle de eski metinlerde yapım ve çekim eklerinin fonksiyonlarının birbirine yakın olduğu belirtiliyor (Başdaş 2006: 5): 
TÜBAR XLI / 2017-Bahar / Orhon Yazıtlarında Ara Ekler

"Bugün sözlük anlamı olmayan sadece gramatik anlamlarlyla var olan ekler, yapım ve çekim ekleri olarak ayrllmaktadır. Ama uzak geçmişte onların kullanımının, dil örgülerinde bazen içiçe geçtiği de görülmektedir." (Karasoy 2004: 3).

Yapım ve çekim ekleri dışında da ek gruplarının olması birçok dil bilimci tarafından kabul görmektedir. Örneğin, Zikri Turan yapım ve çekim ekleri dişında yedi ek grubunun daha olduğunu belirtir (Turan 2007), Gürer Gülsevin $+k i$ (ilgi eki), $+s l z$ (yokluk eki), $+l$ (varlık eki) eklerini tür değiştiren eklerine dâhil eder (Gülsevin 2004: 1278). Bazı ekler daha temel çekim ekleridir, bazıları ise yapım ekine yaklaşır (Erdem 2011: 82). Devamlılık yaklaşımı (continuum approach) yapım ve çekim eklerini derecelendirmeye tabi tutar (Erdem 2011: 83). Yapım ve çekim arasındaki farkın devamlı olduğu görüşünün öncüllerinden biri de Baybee'dir. Payne de bu iki kategori arasında keskin bir fark olmadığını söyler (Kibrik 2005: 4). Melçuk çekimsel anlamlar (gramem) ve yapımsal anlamlar (derivatem) arasında kvazi-gramemlerin de olduğu kanısına varır. Bunlar düzenlilik açısından gramemleri hatırlatsa da kullanımı mecburi değildir (Kibrik 2005: 5). Yapım ve çekim ekleri arasında geçit alanın olmasının asıl sebebi art zamanlı değişim olabilir (Kibrik 2005: 6), yani yapım ve çekim ekleri biri diğerine dönüşebilir. ayrilır:

Yapım ve çekim ekleri arasında kalan alana dâhil olan ekler üç gruba

a) Her ikisine ait olan eklerin varlığı: -ing.

b) Hiç birine ait olmayanların varlığı: - 's.

c) Hangisine ait olduğu bilinmeyenlerin varlığı (Kibrik 2005: 6).

Biz ara ekler demekle özellikle birincileri kastediyoruz.

Yapım ve çekim ekleri arasındaki farklar çeşitli şekillerde anlatılmıştır. Örneğin, M. Ergin yapım ve çekim eklerinin aşağıdaki özelliklerini ileri sürer:

a) Çekim eklerinin fonksiyonu dışarıya uzanır. Yapım eklerinin fonksiyonu kelimenin hudutları içinde kalır. lik yapmaz.

b) Çekim ekleri birleştiği kök veya gövdenin anlamında bir değişik-

c) Çekim eklerinin kullanım alanları yapım eklerinden daha geniştir (Ergin 1967: 117-118). 

tar:

M. Erdem ise çekim ve yapım eklerini ayıran özelliklere şunları ka-

a) Zorunluluk (obligatoriness).

b) Söz dizimsel ilgililik (syntactic relevance). Türetimde kelimenin söz dizimsel kategorisinin değişmesi söz dizimsel bir gereklilikten kaynaklanmaz.

c) Söz dizimsel kategorinin ve anlamın değişmesi (change of syntactic category). Çekim ekleriyle aynı sözlük biriminin farklı şekilleri ortaya çıkar. Yapım ekleriyle ya kategori değişir ya da aynı kategori devam eder.

ç) Anlamsal farklılık (semantic difference). Anlamsal bir ilgililik çekim eklerinde görülmez. Anlamsal ilgiden dolayı türetim ekleri kelime köküne daha yakındır.

d) Anlamsal düzenlilik / düzensizlik. Çekim daha düzenlidir.

e) Bitimlilik. Çekime girmiş kelimeler yeni bir türetime girmez.

f) Psikolengüistik farklılık. Düzenli çekim şekilleri, otomatik bir işlem gibi doğrudan eklenir.

g) İlgililik özelliği. Çekim kategorilerinin anlamları kelime tabanıyla daha az ilgilidir.

g) Çekim kategorileri tekrarlanmaz

h) Booij'e göre, konuşma zorluğu (aphasia) çeken hastalar çekim eklerini söylemekte zorlanır fakat türetim hatası yapmazlar (Erdem 2011: 75-82). Demek ki yapım eki sözcüğün bir parçasına dönüşür, bu nedenle de onun söylenmesi sözcüğün söylenmesi ile birlikte gerçekleşir.

Buraya çekimin türetimden daha işlek olduğu da eklenebilir. Örneğin, bir ismin çokluk eki kolayca tahmin edilebilir (Erdem 2011: 78). Yapım ekleri ise anlam ve şekilce çeşitli kısıtlamalarla karşılaşır. lirtmektedir:

L. Bauer çekim ve yapım eklerini ayırmak için beş temel özellik be-

a) Anlam düzenliliği;

b) Verimlilik;

c) Zorunluluk;

ç) İlgili ek gruplarının ölçüsü; 
TÜBAR XLI / 2017-Bahar / Orhon Yazıtlarında Ara Ekler

d) Ek siralanmas1 (Bauer 2004: 291).

Ara ekler olarak sunulan biçim birimlerin bazıları neredeyse hiçbir yapım özelliği taşımaz, anlam değişikliğine yol açmaz, diğer çekim eklerinden farklı söz dizimi özelliği taşımaz ve kullanımında zorunluluk yoktur. Burada ele alınan eklerse yapım eklerine bir az daha yakın olan ve her iki türün özelliğini taşıyanlardır.

Olumsuzluk eki de ara ekler arasında sunuluyor, bunun nedeni bir fiilin olumsuzluk eki alıp almamasının daha keyfî olması, yani burada bir zorunluluk olmamasıdır. Ancak olumsuzluk tam bir gramer kategorisidir, bu ek sözcüğe yeni bir anlam katmaz, yani burada sözcük yapımından söz edilemez. Bazı dil bilimciler tarafından isimlerde olumsuzluk eki olarak görülen ve - $m a$ kiyle kiyaslanan $+s ı z$ ekiyse ismi olumsuz yapmaz, o isimle ilgili olumsuz bir sifat türetir. Örneğin, tuzsuz tuzun olumsuzu değil, ancak tuzlunun olumsuzu olabilir. M. Ergin $+s ı z$ ve $+l l$ eklerinin işleklik derecesinin çekim eklerine yakın olduğunu belirtir (Ergin 1967: 152). M. Erdem'e göreyse, "-mA kalıcı isimler yapmazken $-s X z$ ve -lX kalıcı isimler türetmektedir." (Erdem 2011: 81). Şekil yapan eklerden biri olarak görülen olumsuzluk eki aslında tam bir çekim ekidir, bütün fiillere eklenir ve hiçbir ekstra anlam ortaya çıkarmaz. Aynı şey isimlerin çokluk ekiyle ilgili de söylenebilir.

\section{İsim soylu sözcüklerde ara ekler}

Orhon yazitlarındaki ara eklere isim soylu sözcüklerde $+l l \breve{g}$, $+s l z$, $+k i,+c ̧ a$, fillerde ise çatı ekleri dâhildir.

Bunların bir kısmı durum eki diye de nitelendirilir: araç, aitlik, yön ve eşitlik durumları (Ergin, Korkmaz, Bozkurt, Eker). T. Banguoğlu "kimli" ve "kimsiz durumlarl"nı gösterir. O kimle, kimce, kimli ve kimsiz hâllerini "dışçekim hâlleri" olarak sunar ve bunların üretim eklerine yaklaştıklarını gösterir (Banguoğlu 1974: 329). Ancak yön gösterme, araç ve eşitlik durum eklerinin çekiminin Eski Türkçede bugünkünden daha düzenli olduğu söylenir (Erdem 2011: 78).

+ l $\breve{g} /+$ lig/+luğ/+lüg eki Orhon yazıtlarında sıkça kullanılır: kağanlı̆̆ 'hakanlı', yaraklı̆ 'silahlı', atlı̆ 'atlı', külig 'şöhretli', ärklig 'güçlü', täblig 'hilebaz, yalanc1', kürlig 'hilebaz, yalanc1', künlig 'cariyeli', kullığ 'köleli'. Günümüzde çoğunlukla $\breve{g} / g$ sesi olmadan kullanılmaktadır, örneğin tuzlu, atll, saygll, üzüntülü (Türkiye Türkçesi) (Kononov 1956: 140141); davuslı 'sesli' (Karakalpakça) (Baskakov 1952: 193); küçli 'güçlü' (Özbekçe), akıllı (Türkmence), a ylı (Tatarca), a tlı (Başkurtça), arla 'kocalı' (Çuvaşça) (Sevortyan 1966: 58). 
Bu ek kökte belirtilmiş nesneye sahip olma anlamı oluşturur. Bu nedenle de "sahiplik eki" diye tanımlanır (Ganiyev 2011: 646; Baskakov 1952: 193). Bu ekin iyleik eki fonksiyonunda olduğunu belirtenler de vardir (Dmitriyev 1948: 68).

Genelde sıfat yapım eki olarak kabul görmesine rağmen çekim eklerine benzer özellikler de taşır:

a) Gramer anlamı oluşturur: sahip olma.

Nän yerdäki kağanlığ bodunka... (Tonyukuk 56) 'Her hangi bir yerdeki hakanlı halka'

$\mathrm{Bu}$ türk bodunda yaraklı̆ yăğğ kältürmädim, tügünlig atığ yügürtmädim (Tonyukuk 54) 'Bu Türk halkı üzerine silahlı düşman getirmedim, düyümlü at sürdürmedim’ halk1...'

...külig bägläri, bodunı... (Bilge Kağan Doğu 1) '... şöhretli beyleri,

Ol ödkä kul kullı̆g, kün küylig bolmış erti (Kül Tigin Doğu 21) 'O zaman kul kul sahibi, cariye cariye sahibi oldu'

Bir örnekte bu ekin sahip olma, kendinde bulundurma anlamı daha kuvvetli olmuştur:

Korğu eki-üç kisiligin täzip bardı (Bilge Kağan Doğu 41) 'Korkarak iki-üç kişi ile birlikte (yanında iki-üç kişi varken) kaçıp gitti'

Burada kaçan insanın iki-üç kişiyle birlikte kaçtığı belirtilir, yani +lig o insanın iki-üç kişiye sahip olduğunu, +in alet durumu ekiyse onlarla birlikte hareket ettiğini gösterir, +lig ve + in eklerinin buradaki görevi $+s i z$ ve + in eklerinin birlikte kullaımına çok benzemektedir.

Hatta -ik ekiyle birlikte diğer bir gramer kategorisi olan zarf fiil anlamı bile oluşturur:

Yuyka eriklig toplağalu uçuz ermiş, yinçgä eriklig üzgäli uçuz (Tonyukuk 13) 'Yufka iken toplamak kolaymış, ince iken kırmak kolay'

Bu görevde +li eki de kullanılabilir:

Otuz artukı bir yaşıma karluk bodun bunsız erür barur erikli yağı boltı (Bilge Kağan Doğu 28-29) 'Otuz bir yaşımda karluk halkı dertsiz yaşarken düşman oldu'

b) Anlam kısitlamasına girmeden bütün isimlere eklenir. 
TÜBAR XLI / 2017-Bahar / Orhon Yazıtlarında Ara Ekler

... küçlig alp kağanımda adıralu bardııı (Ongin 12) ‘ ... güçlü kahraman hakanımdan ayrılıp gittiniz'

... başlı̆̆ğg yüküntürtim, tizligig sökürtim (Bilge Kağan Kuzey 10) '... başlıyı baş eydirdim, dizliyi diz çöktürdüm'

...tabğaç bodun täbligin kürlig üçün, armakçısın üçün... (Kül Tigin Doğu 6) '... Tabğaç halkı hiylekar ve sahtekar olduğu için, yalancı olduğu için...'

...Tabğaç atllğ süsi bir tümän artukı yeti bin süg ilki kün ölürtim (Bilge Kağan Güney-Doğu) ‘... Tabğaç atlı ordusundan on yedi bin orduyu ilk gün öldürdüm'

Ölüg uyarlı̆ ermis... (İhe Ashete I arka 1) ‘Ölü nüfuzluymuş’

Üzä teyri erklig... (İhe Ashete II 1) 'Yukarıda Tanrı güçlü'

+lig ekini almış sözcükte mecazi anlamlı kullanıma da rastlanır:

... kırğağlığ kutayın, äkinlig isigtin, özläk atın, adğırın, kara kisin... (Bilge Kağan Kuzey 11) '... kenarlı ipeğini, ekinlik tahılını, cins atını, aygirın1, siyah samurunu...'

Burada kirğăglı̆ ‘kenarı olan’ sözcüğü ‘kesilmemiş’ anlamı kazanmiştır.

c) Sözcük öbekleriyle kullanılır, örneğin burhan kutınlığ 'Buda azametli' (kut 'azamet, devlet') (Gabain 1988: 47); üküş atlığ ögrünçün yook 'çok atı olan insan;n teminat; yok' (Irk Bitig 54) (Recebli 2009: 519). Bu özellik Orhon yazıtlarında da görülür:

Eki eltäbärlig bodun... (Bilge Kağan Doğu 38) 'İki elteberli halk...’

....anta yerüki Sük başlığ soğdak bodun kop kälti (Tonyukuk 46) ‘...o yerdeki Sük'ün başında durduğu Soğdak halkının hepsi geldi'

Iğar elligdä, lğar kağanlığda yäg k1ltım (Kül Tigin Doğu 29) ‘Güçlü devleti olanlardan, güçlü hakanı olanlardan daha iyi yaptım'

$\mathrm{Bu}$ özellik de sonraki dönemlerde varllğ̆ını korumuştur. Örenğin, oẑon säsle 'uzun saçlı', kara küẑle 'kara gözlü', ak yözle 'beyaz yüzlü'(Dmitriyev 1948: 68).

Bir örnekte ölçü birimi anlamı oluşturur:

Anın barmıs, ayar yatıp bir atlı̆g barmıs, tiyin... (Tonyukuk 24) 'Onunla gitmiş, orada uyuduktan sonar bir at mesafesi kadar gitmiş, diye...' 
32

TÜBAR XLI / 2017-Bahar / Arş. Gör. Dr. Aysel AHMADOVA kullanilır:

+ lı̆ eki Orhon yazıtlarında sözcükleri birbirine bağlamak için de

...inili-eçili kinsürtügin üçün bägli-bodunlığ yoyşurtukın üçün... 'kardeşlerle ağabeyleri birbirine karşı kışkırttığı için, beylerle halkı birbirine düşman ettiği için...' (Kül Tigin Doğu 6).

Bilindiği üzere yapım ekleri sözcük daha herhangi bir öbek oluşturmamışken ona eklenir ve yeni bir sözcük yapar, yalnızca çekim ekleri sözcük öbeği oluşturduktan sonra kullanılır. Yukarıdaki burhan kutınlı̆̆ 'Buda

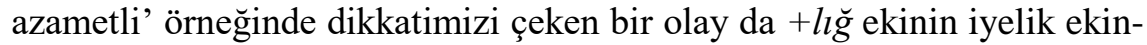
den sonra gelmiş olmasıdır ki, bu da yapım değil, çekim eklerine has olan bir özelliktir.

M. Ergin $+l l$ ekini vasıf isimleri yapan ek olarak sunar ve bu isimlerin sifat olarak kullanılabildiğini belirtir (Ergin 1967: 150).

Çağdaş Türk dillerinde + $l i$ ekinin başka bir işlevi de var ki burada $+l i$ eki almış sözcük sahiplik değil, aitlik bildirir. Bu işlevin oluşması için +li eki yer anlamlı sözcüklere eklenmelidir: ankaral, istanbullu, bakülü vs. Bu özelliğe Orhon yazıtlarında rastlamıyor olmamız onun daha sonraki dönemlere ait olması görüşünü ortaya çıkarır.

+ slz/+siz/+suz/+süz eki Altayca, Tuvaca, Hakasça, Şorca ve Yakutça dışındaki yani Sibir'deki Türk dilleri dışındaki bütün çağdaş Türk dillerinde kullanılmaktadır (Kononov 1980: 107), örneğin küçsiz 'güçsüz' (Kazakça), tuzsuz 'tuzsuz' (Karayca), sansız 'sayısız' (Karaçay-Balkarca), colsuz 'yolsuz' (Kırgızca), kipsiz 'şekilsiz' (Hakasça), sětsěr 'sütsüz' (Çuvaşça) (Şçerbak 1977: 99); kulhıẑ 'elsiz', eşheẑ 'işsiz', toẑhoẑ 'tuzsuz' (Başkurtça) (Dmitriyev 1948: 73); tuvrılıksız 'şerefsiz' (Karakalpakça) (Baskakov 1952: 196); antsız 'yeminsiz', tınçsız 'rahatsız', uyatsız 'vicdansız' (Karaçay-Balkarca) (Habiçev 1971: 255). Orhon yazıtlarında yaygindır: bunsız 'dertsiz', buysız 'sayısız', aşsız 'yemeksiz', idisiz 'sahipsiz', biligsiz 'bilgisiz', aşsız 'yemeksiz', tonsız 'giysisiz', buysız 'sayısız', bunsız 'dertsiz', kalısız 'kalıksı (tamamen)', kärgäksiz 'gereğinden fazla', sansız 'sayısız', keçigsiz 'geçitsiz'. Kökte belirtilmiş nesneye sahip olmama, onun yokluğu anlamı oluşturması nedeniyle "yokluk eki" olarak da bilinir (Ganiyev 2011: 646). Bazense bu ek "yokluk ve eksiklik" eki diye isimlendirilir (Teres 2013: 341). +sız ekiyle yapılmış sıfatlara da "yokluk slfatlart" denir (Kononov 1980: 107; Tekin 2003: 84).

+lig ekinin sahip olduğu özellikler + siz ekinde de vardır:

a) Gramer anlamı oluşturur: yokluk. 
TÜBAR XLI / 2017-Bahar / Orhon Yazıtlarında Ara Ekler

...idi oksız kök türk ança olurur ermis (Kül Tigin Doğu 3) ‘... sahipsiz, kabilesiz Göktürkler öylece oturuyorlarmış’

İçrä aşsız, taşra tonsız, yabız, yablak bodunka üzä olurtım (Kül Tigin Doğu 26) 'İçeride yemeksiz, dışarıda giysisiz, zayıf, kötü halk üzerinde hakim oldum'

... biligsiz kağan olurmıs erinç, yablak kağan olurmıs erinç (Kül Tigin Doğu 5) 'Bilgisiz hakanmış, cahil hakanmış'

b) Anlam kısitlamasına girmeden bütün isimlere eklenir.

...on ok süsi kalısız tasıkd1 - tir (Tonyukuk 33) ' $\ldots$ on ok halkı kaliksız (hepsi birden) isyan etti - der'

Edgü özläk atın, kara kisin, kök tiyinin sansız kälürip kop kotı (Bilge Kağan Güney 12) 'İyi cins atını, kara samurunu, mavi sincabını sayısız getirip hepsini koydu'

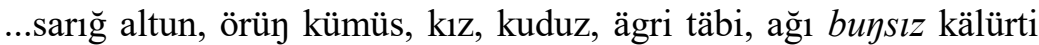
(Tonyukuk 48) ' ... sarı altın, parlak gümüş, kız, gelin, hörgüçlü develer, hediyeleri sayısız getirdi'

Hatta bir örnekte sıfata bile eklenmiştir:

Begleri bodunı tüzsiz üçün ... (Kül Tigin Doğu 6) 'Beyleri halk1 doğru olmadığg için...'

Tüzsiz sözcüğünün eski Uygur yazıtlarında da kullanılmış olması (Drevnetyurkskiy 1969: 603) onun Orhon yazıtlarında geçmesinin tesadüf olmadığını kanıtlar.

Bu bazı çağdaş Türk dillerinde + siz ekinin $+l i$ ekli sıfatlara eklemesine benzer bir özellik olarak görülebilir: saklllıksız adam, bellisiz (Özkan 1996: 104).

Çuvaşçadaki + săr $/+$ sěr eki yokluk hâlinin eki olarak kabul edilir (Şçerbak 1977: 99). Yani Çuvaşçada bu ekin çekim eki olması çoğunlukça kabul edilmiş ve gramer kitaplarına dâhil edilmişdir.

"Ekin yaygın ve işlek kullanılışının, isim çekim eklerinden sonra da yer almasını sağladığı düşünülebilir. Türkçede böyle bir kullanım yoktur." (Üstüner 2001: 181) dense de, -slz ekinin Orhon Türkçesi sonrası dönemde çekim eklerinden (iyelik eklerinden) sonra da kullanıldığı görülür: cema-

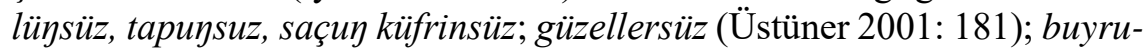
ğınsuz (Ergin 1967: 152); vätänimsiz, ailämsiz (Sevortyan 1966: 82); annemsiz, klzımsız (Üstünova 2001: 124). 
34

TÜBAR XLI / 2017-Bahar / Arş. Gör. Dr. Aysel AHMADOVA

M. Ergin $+l \iota$ eki gibi bu ekin de vasıf isimleri oluşturduğunu söyler (Ergin 1967: 152). A. M. Şçerbak bu eki almış sözcüklerin aynı derecede hem sıfatlara hem de ismin hal şekillerine ait edilebileceği görüşünü belirtmesine rağmen, bütün isimlerin bu ekleri alamayacağını da belirtir (Şçerbak 1977: 99).

Türkolojide $+s l z$ ekinin $+l l \breve{g} \sim+l l$ ekinin zıt anlamlısı olduğuna dair görüşlerin yaygın olmasına rağmen (Kononov 1980: 107; Dmitriyev 1948: 73) + slz ekinin fonksiyonları daha geniştir. Bu ek eski Türkçede vasıta hali ekinin olumsuz şeklini ifade etmek için kullanılmıştır. Nitekim aynı özellik eski Türkiye Türkçesi için de geçerlidir (Üstüner 2001: 178).

+ siz ekli sıfatlar zarf olarak kullanılmaya eğilimlidir: tirdi'

...kärgäksiz kälürti (Bilge Kağan Güney 11) 'gereğinden fazla ge-

...subsız keçdim (Bilge Kağan Güney-Doğu) '...susuz geçtim'

Ancak Orhon yazıtlarında bu her zaman mümkün olmamış ve + siz ekli sözcüğün zarf olarak kullanılabilmesi için alet durumu eki olan $+i n$ ekini de alması gerekmiştir: aştık'

Altun yısı̆ yolsızın asdım... (Tonyukuk 35) 'Altun ormanını yolsuz

Ertis ügüzig keçigsizin keçdimiz... (Tonyukuk 35) 'İrtiş nehrini geçitsiz geçtik'

Bu durumda $+s ı z$ eki $+l a$ ekinin görevini üstlenir. Aynı ekin kullanım yerine göre kâh $+l \grave{g} \sim+l l$ kâh da $+l a$ ekinin zıt anlamlısı, olumsuzu olarak kullanılması bu ekler arasında da bir ilişki olabileceği ihtimalini ortaya çıkarır. "Bugün "benimle" ifadesinin olumsuz şekli olarak "bensiz" kullanilmaktadır" (Üstüner 2001: 183). Bu özellik +ll ve +la ekleri arasındakı ilgiyi gösterir. Zaten Tahir Nejat Gencan da $+s l z$ ekini $+l l$ ve ilenin olumsuzu olarak görür (Gencan 1979: 199), yani o da +lığ ve ile, +la arasindaki ilgiyi kabul eder. L. A. Pokrovskaya da $+l l$ ekinin Gagauzcada $+l a$ ekinin anlamın ifade ettiğini belirtir. Aynı eserde $+l l$ ekli sıfatların da zarf olarak kullanımına dair örnekler görüyoruz:

Uroklar geçerlar xızlı, şen hem faydalı 'Hızlı, eylenceli ve faydalı dersler yapiyorlar'

Büün işleris çesna, saygllı kolhozda 'Bu gün kolhozda dürüst ve saygılı çalışıyoruz’ (Pokrovskaya 1964: 89). 
TÜBAR XLI / 2017-Bahar / Orhon Yazıtlarında Ara Ekler

Çekim eklerinden sonra $+s ı z$ ekini almış sözcüklerin genelde zarf olarak kullanılması bu ekin zarf eki görevinde çekim ekine yakınlığını doğrular. Aynı özellik şahıs zamirlerinin $+s ı z$ eki alması için de söylenebilir. Çağdaş Türk dillerinden bu konuyla ilgili şu örneklere başvurabiliriz: $90)$.

Elsiz, ayaksız durarım, ama sensiz duramam (Pokrovskaya 1964:

M. Ergin bu ekin olumsuz isim yapan ek olarak anıldığını söyler (Ergin 1967: 152). Fakat yazarın kendisinin de söylediği gibi $+s l z$ ismi olumsuzlaştırmaz, onu sifata çevirir ve oluşan sıfat olumsuz anlama sahiptir. "Türkçede adlara gelen olumluluk, ya da olumsuzluk eki söz konusu olmadiğ gibi, eklerden birini alan her sözcüğün diğerini mutlaka aldiğını da söyleyemeyiz." (Üstünova 2001: 119). +siz olumsuzluk eki değildir çünkü fiillerdeki olumsuzluk eki -ma sözcüğün ait olduğu türü değiştirmezken, $+s ı z$ eki ismi sıfata dönüştürür. Ayrıca $+s ı z$ ekini alan sözcükler olumsuzsa, onların olumlu karşılıkları yalın isimler değil, $+l l$ ekini alan sözcüklerdir. Peki $+l l$ ekini alan sözcüklere olumlu diyorsak bu eki almamış sözcüklere ne ad verilmelidir? (Üstünova 2001: 121).

“...çekim sözdizimi sonrası bir işlemdir.” (Erdem 2011: 82), yani çekim cümlede, sözcüklerin diğerleri ile birleşmesi anında ortaya çıkar. $+l l$ ve $+s ı z$ ekleri bu özelliği taşımaz. Bu eklerin kullanılmasının nedeni nitelik bildiren yeni sözcüklerin yani yeni sıfatların ortaya çıkması ihtiyacıdır.

“-IX ve -sXz eklerinin neredeyse bütün isimlerle düzenli çekimlenebilmesi ve tahmin edilebilir anlamlar oluşturması bu ekleri az da olsa çekim eki sınırına götürür." (Erdem 2011: 86). Türetim anlam sınırlamalarını beraberinde getirir (Erdem 2011: 85). +ll ve $+s l z$ eklerinde bu sinırlandırma az da olsa gözlemlenir. Bazı isimler bu ekleri alamazlar, örneğin güzellikli, kahramanlıklı vb. sözcükler türetilemiyor. Bunun nedeni yapım eki ile isme dönüştürülmüş bir sıfatı yeniden sıfatlaştırmaya ihtiyaç olmamasidir.

Şunu da dikkate almak gerekir ki, ädligsiz 'değersiz' (äd 'madde') (Gabain 1988: 47) örneğinde de görüldüğ̈̈ üzere, +lı̆̆ ve $+s l z$ ekleri aynı sözcüğe de eklenebilir. Bu özellikse çekim kategorileri için geçerli değil çünkü bir sözcüğe aynı kategoriye birden fazla çekim eki getirilemez.

$+k i /+g i /+\breve{g l} /+k u$ eki çağdaş Türk dillerinde ve diğer Altay dillerinde kullanılır. Orhon yazıtlarında hemen hemen bütün hâllerde olan isimlere eklenir: çölgi 'çöldeki', kurıyaku 'gerideki', balıkdakı 'şehirdeki', içräki 'içerideki', ilki 'ilk'. Örneğin, 
36

TÜBAR XLI / 2017-Bahar / Arş. Gör. Dr. Aysel AHMADOVA

Illki sü taşıkmış erti, ekin sü ebdä erti (Bilge Kağan Doğu 32) ‘ìlk ordu dışarı çıkmıştı, iki ordu evdeydi'

Besbalık içräki nä kişi etin... (Bilge Kağan Doğu 28) 'Beşbalık içindeki hangi insanlardı'

Sözcük öbekleriyle kullanılır:

Bödgä özim olurıp bunça ağır törüg tört bulundaku (bodunğa it)dim. (Bilge Kağan Doğu 2) 'Tahtta kendim oturup bu kadar ağır kanunu dörd taraftaki (halk için yap)tım'

Näy yerdäki kağanlığ bodunka... (Tonyukuk 56) 'Her hangi bir yerdeki hakanlı halka'

Oluşturduğu anlam sebebiyle A. N. Kononov (Kononov 1956: 77), N. K. Dmitriyev (Dmitriyev 1940: 59), F. Zeynalov tarafindan "iyelik eki" (Zeynalov 2008: 114), M. Ergin tarafindan "aitlik eki" ("ikinci bir iyelik eki”) (Ergin 1967: 214), G. Gülsevin tarafından "ilgi eki" (Gülsevin 1997: 117) olarak adlandırılır.

$+k i$ ekini iyelik eklerinden ayıran özellik (ilgi ekinden sonra gelmesi hariç) sıfat yapmasıdır. Ancak bu eki almış sözcükler isim yerine geçebilir:

...balıkdakı tağıkmıs, tağdakı inmis... (Kül Tigin Doğu 12) '...şehirdeki dağa çıkmış, dağdakı inmiş...'

$+k i$ ekinin çekim eklerinden sonra kullanılabilmesini M. Ergin bu ekin edat kökenli olması ile açıklar (Ergin 1967: 153).

+ $k i$ eki Orhon Türkçesinden sonrakı dönemde de kullanılmaya devam etmiştir: arkandağl, evvelki, ilerüki, kankl, sonră̆l, yarınğl (Eski Anadolu Türkçesi) (Gülsevin 1997: 117); Bügüngü künnü tamblası da bardı 'Bu günün yarını da var'; Küzgü cel cerni bereketin alır 'Sonbahar rüzgarı yerin bereketini alır' (Karaçay-malkar) (Habiçev 1971: 258). Ancak burada çeşitli farklı1ıkları da göz ardı etmemek gerekir. Şöyle ki Orhon yazıtlarında bu ek ilgi ekinden sonra kullanılmaz, sonrakı dönemdeyse bu kullanım oldukça yaygın bir hal almıştır. Öte yandan Orhon yazıtlarında yer anlamlı sözcüklere hiçbir ilave eke gereksinim duymaksızın eklenebilen $+k i$ eki sonraki dönemde yalnız bulunma eki almış yer anlamlı isimlere eklenebilmektedir. Orhon yazıtlarındaki bu örnekler $+k i$ ekinin bulunma durumunda olmayan yer anlamlı sözcüklere de eklendiğini kanttlar:

Çölgi az ärig bultım (Tonyukuk 23) 'Çöldeki az askerini buldum’ 
TÜBAR XLI / 2017-Bahar / Orhon Yazıtlarında Ara Ekler

Türk bägläri türk atın 1tı Tab̆̆açğı bäglär Tabğaç atın tutıpan Tabğaç kağanka körmis (Kül Tigin Doğu 7-8) 'Türk beyleri Türk adlarını bırakıp Tabğaçtaki beyler Tabğaç adları alıp Tabğaç hakanına itaat etmiş'

....anta yerüki Sük baslığ soğdak bodun kop kälti (Tonyukuk 46) ' ... o yerdeki Sükün liderlik ettiği Soğdak halkı hepsi geldi'

Bazı çağdaş Türk dillerinde de $+k i$ ekinin yer anlamlı sözcüklere eklenmesi görülmektedir, örneğin, o'rtaa (<*o'rtă̆ $)$ 'ortadaki', üstü̈̈

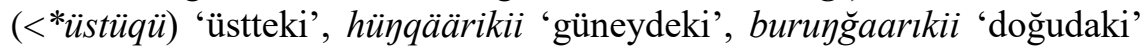
(Tofalarca) (Rassadin 2014: 106).

Sonraki dönemlerdekinden farklı olarak Orhon yazıtlarında $+k i$ eki yönelme durumundaki sözcüklere de eklenebilmiştir:

Ötükän yerig konmıs tiyin esidip bäriyäki bodun, kurlyakl, öyräki bodun kälti (Tonyukuk 17) 'Ötüken yerinde yerleştiğini duyup güneydeki halk, batıdaki halk, öndeki halk hepsi geldi'

Ögräki är... (Tonyukuk 25) 'Öndeki asker...’

On tünkä yantakı tuğ ebirü bardımız (Tonyukuk 26) 'On gece yandaki engelin etrafında dolandık'

Çağdaş Türk dillerinin bir kısmında çok sözcüğünün çıkma durumuna $+k i$ ekinin eklendiğini görüyoruz:

Çoktankı umut büün açtı 'Eskiden beri olan umut bu gün gerçekleşti' (Pokrovkaya 1964: 92).

$\mathrm{Bu}$ özellik Orhon yazıtlarında gözlemlenmez.

Aitlik eki $+k i$ hem çekim eki hem de yapım eki olarak sunulur. Bu ek “...iki durum eki arasında yer almaktadır." (Erdem 2011: 80). M. Ergin $+k i$ ekinin de temsil ve vasıf isimleri yaptığını yazar (Ergin 1967: 152). Görüldüğü üzere o, ara eklere dâhil ettiğimiz eklerin birçoğunun sifat değil, isim yaptığını belirtir. Hâlbuki bu eklerde bulunan en önemli yapım eki özelliğinin sözcük türünü değiştirme olduğu söyleniyordu.

Bunlar hem yapım hem de çekim eki özelliğine sahiptir. + lı̆ ekinin "sahiplik", $+s l z$ ekinin "yokluk", $+k i$ ekinin "aitlik eki" olarak adlandırılması onların oluşturduğu anlamları yansıttığından kabul edilebilir.

$\mathrm{Bu}$ üç ekin ortak noktalarından biri de onları almış sözcüklerin göreceli sıfat tanımına tabi tutulmasıdır (Kononov 1956: 140; Şçerbak 1977: 99). Göreceli sıfat, niteliği eşyaya dayanarak sunan sıfat türüdür ve onda sıfatla birlikte isim özellikleri de görülebilir. 
38

TÜBAR XLI / 2017-Bahar / Arş. Gör. Dr. Aysel AHMADOVA

+ça eki üç şekilde nitelendirilir:

a) Son tak1;

b) Sayı isimleri ve zarf yapım eki;

c) Eşitlik durumu eki.

Orhon yazıtlarında +ça ekli sözcükler bunlardır: ança 'o kadar', bunça 'bu kadar', subça 'su gibi' vb.

Örneğin,

Bödgä özim olurıp bunça ağır törüg tört bulundakı (bodunğa it)dim (Bilge Kağan Doğu 2) 'Tahta kendim oturup bu kadar ağır kanunu dört taraftaki halka ulaştırtım'

...bilmäz biligin biltügimin, ödükimin bunça bitig bitidim (Küli Çor 28) '...bilinmez bilgiyi bildiğimi, düşündüğümü bu kadar yazıya yazdım'

Türgis kağan ança timis: benin bodunım anta erür timis (Tonyukuk 21) 'Türgis hakanı böyle demiş: benim halkım oradadır demiş'

Män inilügi bunça başlayu kazğanmasar, türk bodun öltäçi erti, yok boltaçı erti (Bilge Kağan Doğu 33) 'Ben ilk önce bu kadar kazanmasam, türk halk1 ölücekti, yok olacaktı'

Ança olurır erikli oğuzdantan körük kälti (Tonyukuk 8) ‘Öylece otururken oğuzdan casus geldi'

...örtçä kızıp kälti (Tonyukuk 40) ‘...ateş gibi ısınıp geldi’

Bizintä eki ucı sı̄arça artuk erti (Tonyukuk 40) ‘íki ucu bizden yanı yarıya fazlaydı'

Uyğur eltäbär yüzçä ärin ilgärü tä(zip bardı)... (Bilge Kağan Doğu 37) 'Uygur elteberi yüze kadar askerle ileri kaçıp gitti'

Olurtıkıma öltäçiçä sakınığıma türk bäglär, bodun ögürip, sebinip toktamış közü yögärü körti (Bilge Kağan Doğu 2) 'Oturduğumda öleceğini düşünen Türk beyleri, halkı memnun olup, sevinip sakinleşmiş gözü yukarı bakt1'

Teyri tirigdäkiçä... (Kül Tigin Güney-Doğu) 'Gök yüzünde de hayatda olduğu gibi...' 
-ça ekinin sonrakı dönemlerde kullamı da Orhon yazıtlarındaki kullanıma oldukça benzer. Örneğin, Eski Anadolu Türkçesinde boycukca, deriyce, dünyâca sözcüklerinde de bu ek 'kadar' anlamı taşımaktadır (Gülsevin 1997: 115).

A. von Gabain'e göre “aynı zamanda kelime teşkil eden bu ek, muhtemelen, sakatlanmış (verstümmelte) eski bir son çekim edatıdır. Artık, tek başına bir manası olmadı̆̆ı için hal ekleri içine alınmışıır." (Gabain 1988: 65). +ça morfeminin son takı olarak görülmesi Azerbaycan dil biliminde daha yaygındır. Bunun da asıl sebebi bu morfemin kadar son takısı ile aynı işleve sahip olmasıdır (Tanrıverdi 2012: 339; Mirzezade 1990: 207). A. M. Şçerbak da çağdaş Türk dillerinde bu ekin son takıya yakın olduğu görüşünü kabul edenlerdendir (Şçerbak 1977: 155). Bu görüşün kabul edilebilirliğini kanıtlayan bir özellik +ça morfeminin vurgusuz olmasıdır ki, vurgusuzluk yardımcı sözcük türlerinin özelliklerindendir.

$\mathrm{Bu}$ ekin çağdaş Türk dillerinde yapım eki olduğuna dair görüşler yaygındır. M. Erdem bunun nedenini $+c ̧ a$ ekinın bugün isim cinsinden olan bütün kelimelere getirilememesinde görür ve şu delilleri sunar:

a) Kelime türünü devam ettirmesi ya dadeğişiklik yapması.

b) Kendinden sonra iyelik ve diğer durum ekleri alması: açıkçası, delicesine (Erdem 2011: 76-77).

A. N. Kononov da $+c ̧ a$ ekini yapım eki olarak kabul eder (Kononov 1980: 136), hatta bu eki çağdaş Türk dillerinde aktif olan tek zarf yapımı eki olarak görür (Kononov 1956: 300, 309). A. N. Baskakov (1952) ve E. V. Sevortyan (1966) da bu görüşü paylaşırlar.

+ça morfemini çekim eki olarak gören dil bilimciler onu eşittik hâli eki diye nitelendirir (Tekin 2003: 116). M. Erdal bu ekin eşitlik eki adıyla sunulmasının ekin işlevini tam olarak açıklamadığını, ekin eşitlik dışında da anlamlar ifade ettiğini belirtir, örneğin, hudut (limitatif), araç (prolatif) (Erdal 2004: 376-378). Gürer Gülsevin bu ekin aslında eşitlik eki olduğunu belirtmekle birlikte, onun yapım için de kullanılabildiğini kabul eder (Gülsevin 1997: 115).

$\mathrm{Bu}$ üç görüş A. von Gabain'de toplanır ve o $+c ̧ a$ morfemini hem yapım eki olarak görür hem eşitlik halinin eki diye isimlendirir, bu ekin kökeninin edata dayanabilmesini de inkâr etmez (Gabain 1988: 65).

Aslında hâl ekinin kalıplaşması ve yapım ekine dönüşmesi olayı Türk dillerine yabancı değil, araç hali eki $+\imath n$, yönelme hali eki $+r u,+a r u$, 
40

TÜBAR XLI / 2017-Bahar / Arş. Gör. Dr. Aysel AHMADOVA

+ 乌̆aru da sözcük içinde kalıplaşmış̧ır. Türk Dillerinin Karşılaştırmalı Tarihi Grameri'nde +ça eki de belirtilen eklerle aynı kategoriye dâhil edilmiştir (Sravnitelno 1988: 258).

Bu eki yapım ekinden uzaklaştıran, onu çekim ekine ya da son takıya yakınlaştıran bir özellik de onun çekim eki almış sözcüklerle de kullanılabilmesidir. Örneğin,

Köylünçä udız tidi (Tonyukuk 15) 'Gönlünce gönder dedi'

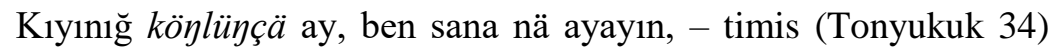
'Cezayı gönlünce söyle, ben sana ne söyleyeyim demiş'

Başka bir özellik de Orhon yazıtlarında bu ekin kullanım sıklığının yoğunluğu ile yapım eklerini değil, çekim eklerini hatırlatmasıdır.

\section{Fiillerde ara ekler}

Fiil çatısı ekleri kimine göre yapım, kimine göre çekim ekidir. Bunun sebebi bir gramer kategorisi oluşturan bu eklerin sözcükte küçük de olsa anlam değiş̧ikliğine sebep olması, bütün fiillerle kullanılamaması, fiilin anlamının bunda etkili olmasıdır.

G. Gülsevin fiilden fiiil yapan ekler içinde çoğunlukla çatı eklerine dair bilgiler verir (Gülsevin 1997: 138-142). A. von Gabain'in fiilden fiil yapan ekler başlı̆̆ 1 altında sunduğu ekler arasında çatı ekleri de yer alır (Gabain 1988: 59-61). N. K. Dmitriyev şöyle yazar: "Fillerden fiil yapma sonucunda çatı kategorisi ortaya çıkar." (Dmitriyev 1948: 179). N. A. Baskakov da çatı şekillerinin fiilden fiil yapma sonucunda oluştuğunu gösterir (Baskakov 1952: 332-333). Türk Dillerinin Karşılaştırmalı Tarihi Grameri'nde çatı şekillerinin çok işlevli olduğu ve çoğunlukla yeni ve yenilenmiş sözlük birimine uygun olduğu gösterilir (Sravnitelno 1988: 270). M. Ergin çatı eklerini çatı kategorisini anmadan fiilden fiil yapan eklerin içinde takdim eder, ancak bu eklerin işleklik derecesi itibariyle çekim eklerine yakın olduğunu da belirtir (Ergin 1967: 190). M. Hüseynzade çatı eklerinin sözün şeklini de anlamını da değiştirmesine dayanarak onları çekim eklerine dâhil eder (Hüseynzade 2007: 124). T. Tekin de çatı eklerini eylemden eylem türeten ekler adiyla sunar (Tekin 2003: 93).

A. N. Kononov çatıyı hem sözcük yapımı hem de çekimine dâhil eden araştırmacılardandır. Onun yazdığına göre fiil çatısında iki başlangıç var. A. N. Kononov'un bir konuyla ilgili fikri daha çok dikkat çekiyor. Şöyle ki o çatı ekinin anlam değişimine yol açtığı zaman şekil yapımı değil, sözcük yapımı işlevini yerine getirdiğini belirtmektedir (Kononov 1980: 173). 
TÜBAR XLI / 2017-Bahar / Orhon Yazıtlarında Ara Ekler

Fiil çatısını fiile ait çekim kategorileri içine alan dil bilimciler de yok değildir. E. V. Sevortyan çatı kategorisi hakkında şöyle yazar:

"Eğer bütün türkologlar tarafindan kabul gören fiilin çatı kategorisinin Türk dillerinde söz dizimi içeriği taşımasını esas alırsak o zaman anlam tipi itibarile onu fiilin çekim kategorilerine ait etmek gerekir." (Sevortyan 1962: 455).

Y. Seyidov fiilin çatı kategorisini çekim kategorisi olarak nitelendirir, çatı eklerini de çekim eklerine dâhil eder (Seyidov 2006: 51, 312). G. Kazımov geçişlilikle çatı eklerini göreceli fiil yapma araçları olarak hatırlatmış, ancak onlardan daha kapsamlı olarak fiilin çekim kategorileri içinde söz etmiştir (Kazımov 2010: 172-173, 183). Z. Budagova çatı eklerini şekil yapan ekler olarak isimlendirmiş ve onları fiil yapım eklerine dâhil etmemiştir (Müasir 2 1980: 208). M. Erdem'e göre: “...çatı ekleri, cümlenin unsurlarını etkileyerek sözdizimsel bir görev üstlenirler ve düzenli çekimlenirler." (Erdem 2011: 86).

Orhon yazıtlarında ve genel olarak Eski Türkçede fiil çatısı ve onu oluşturan eklerin işlevi çağdaş Türk dillerindekine nazaran daha farklıdır:

1. Yazıtlarda çatı ekleri çoğu yapım ekine nazaran daha yaygındır ve bu açıdan çekim eklerine yaklaşır.

2. Yazıtlarda ve genel olarak Eski Türkçede çatı kategorisi daha sistematik olmuştur. Çağdaş Türk dillerinde fiilin anlamı farklı çatıların oluşmasını kısıtlar ve bir fiilin yalnız birkaç çatı şekli ortaya çıkar. Eski Türkçedeyse aynı bir fiil neredeyse bütün çatıların eklerini almak imkânına sahip olmuştur: basın-, bastt-, basık- (Orhon yazıtları), basıl-, bassık- (Kutadgu bilig), basış-, bastur-, basur- (Divanü lügat it-türk); altı- (Orhon yazıtları), alduz-, alın-, alsık-, altur- (Divanü lügat it-türk), alıl-, alı̧̧- (Kutadgu bilig); kllın- (Orhon yazitları), kllıl- (Uygur yazitları), klldur- (Kutadgu bilig), klltur-(Divanü lügat it-türk) vs.

3. Yazıtlarda bir fiilin aynı çatısı farklı eklerle oluşabilir: kälür-, kältür-.

4. Orhon yazıtlarında ve de diğer eski Türk yazılı kaynaklarında fiil çatısı ekleri ait olduğu çatının anlamını ifade etmiş ve bu anlamdan dişarı çıkma, çatı ekinin sözcüğün anlamını değiştirmesi durumları oldukça azdır. Hâlbuki çağdaş Türk dillerinde bu özellik güçlüdür:

“...çatı şekilleri muntazam değil, sık-sık çekim açısından çatıya ait olmayan anlamlar da ifade etmekte (kareketin tekrarı, yoğunluğu, devam- 
42

TÜBAR XLI / 2017-Bahar / Arş. Gör. Dr. Aysel AHMADOVA

lılı̆gl) ve kolayca sözlük bilimine doğru kaymaktadır. Fiil esasına çatı eklerinin gelmesi bazen ona tamamlaylcı anlam getirmez, onun önceki anlaminı değiştirir." (Sravnitelno 1988: 107).

5. Türk dilleri için çatı kategorisinin tam bir çekim kategorisi statüsünde kabul görmesine engel olan bir özellik aynı bir sözcüğe birkaç çatı ekinin gelebilmesidir. Hâlbuki aynı bir sözcüğe aynı kategoriye ait yalnız bir çekim eki gelebilir: $y a^{o} z$ dirll- (Özbekçe), keyindiril- 'giyindirilmek' (Karayca), yuvundur- 'yıkatmak (Karaçay-balkarca), körühünner- 'görüştürmek' (Yakutça), yaẑẑırt- 'yazdırtmak' (Başkurtça) (Sravnitelno 1988: 101), segirdüş, yığlın-, katıllş-, depelenil-, sevniş-, dirşür-, indürünil-, degşüril-, çıkarınıl- (Eski Anadolu Türkçesi) (Gülsevin 1997: 141); yazdlrılmak, okutulmak (Türkiye Türkçesi). Bu özellik Orhon yazıtlarının dilinde daha oluşmamıştır.

Orhon yazıtlarında çatı ekleri çoğunlukla çatı anlamı oluşturur:

Edilgen çatı:

Boğuzlan- 'boğazı kesilmek': Yerçi yer yayılıp boğuzlantı (Tonyukuk 26) 'Rehber yeri yanlış söylediği için boğazı kesildi'.

Basın- 'yenilmek': ... basınığma yağı̆̆ kälürir ertim (Tonyukuk 53) '...yenilen düşmanı getiriyordum'.

Dönüşlülük çatısl:

Etin-/itin- 'yapılmak, toplanmak': Yağı bolıp itinü, yaratunu umaduk yana içikrnis (Kül Tigin Doğu 10) 'Düşman olup, yapılmayı, yaratılmayı beceremediğinden yine itaat etmiş'.

Yaratın- 'yaratılmak': Yağı bolıp itinü, yaratunu umaduk yana içikrnis (Kül Tigin Kuzey 10) 'Düşman olup, yapılmayı, yaratılmayı beceremediğinden yine itaat etmiş'.

Arll- 'yorulmak, zayıflamak': ...kop anta alkıntığ, arıltığ... (Kül Tigin Güney 9) '...hepsi orada yoruldu, zayıflad1...' .

Kılın- 'yaratılmak, yetiştirilmek': Üzä tepri, asra yağız yer kılıntukda ekin ara kisi oğlı kılınmış (Kül Tigin Doğu 1) 'Yukarıda Tanrı, aşağıda kahverengi yer yaratıldıkta ikisi arasında insanoğlu yaratılmış’; Bilgä Tonyukuk ben özüm Tabğaç ilinä kılıntım (Tonyukuk 1) 'Ben bilge Tonyukuk kendim Tabğaç devleti için yetiştirildim'.

Adırıl- 'ayrılmak': Türk bodun kanın bolmayın Tabğaçka adırıltı, kanlantı (Tonyukuk 2) 'Türk halkı hanı olmadan Tabğaçtan ayrıldı, han kazand1'. 
TÜBAR XLI / 2017-Bahar / Orhon Yazıtlarında Ara Ekler

Tiril- 'toplanmak': Yarıs yazıda tirilälim, - timis (Tonyukuk 33) 'Yarış çölünde toplanalım, - demiş'.

Yazın- "yanlış yapmak, günah işlemek": Bizinä yạılukın yazındukın üçün kağanı elti... (Kül Tigin Doğu 19) 'Bize karşı yanlış yaptığı, günah işlediği için hakanı gönderdi...'.

Tälin- 'delinmek': Üzä tẹri basmasar, asra yir tälinmäsär... (Kül Tigin Doğu 22) 'Üstte Tanrı basmasa, aşağıda yer delinmese...'.

\section{Ettirgen çatı:}

Bitit- 'yazdırmak': Türk bilgä kağan ilijä bititdim bän Bilgä Tonyukuk (Tonyukuk 58) 'Ben bilge Tonyukuk bilge türk hakanının devletinde yazdirdim'.

Basıt- 'yeniltmek': Yelmä, karağu edgüti urğıl, basıtma, - timis (Tonyukuk 34) 'İstihbaratı, bekçileri iyice kur, yenilgiye uğratma, - demiş'.

Tutız- 'yakalatmak': ... tutıztı. Ekisin özi altızdı (Kül Tigin Doğu 38) '... yakalattı. İkisini kendi aldırdı'.

Altız- 'aldırmak': ... tutıztı. Ekisin özi altızdı (Kül Tigin Doğu 38) '... yakalattı. İkisini kendi aldırdı'.

Işteşlik çatısı:

Sözleş- 'birbirine danışmak': İnim Kül tigin birlä sözläşdimiz (Kül Tigin Doğu 26) 'Kardeşim Kül tiginle birbirimize danışdık'.

Kunuş-/konus- 'birbirini soymak': ... konuşmak, tartışmak 'birbirini soymak, çekiştirmek' (3. Orhon Güney 9).

Tartış- 'çekiştirmek': ... konuşmak, tartışmak 'birbirini soymak, çekiştirmek' (3. Orhon Güney 9).

Sü̈üs- 'savaşmak' (Kül Tigin Doğu 15): ... sü̈üsip süsin sançd1, elin altı... (Küli Çor 22) ‘... savaşıp ordusunu yendi, devletini ald1...'.

Kabıs- 'birleşmek': ...Tabğaç, Oğuz, Kitañ - bu üçägü kabisar... (Tonyukuk 12) '...Tabğaç, Oğuz, Kitan - bu üçü birleşirse...'.

Kaçış- 'kaçışmak': Ol kan yok boltukda kisrä el yitmis, 1çğınmıs, kaçışmıs (Ongin 1) 'O han yok olduktan sonra devlet kaybolmuş, mahv olmuş, kaçışmış'.

Yazıtlarda çatı ekleri nadiren anlam değişikliğine sebep olur: 
44

TÜBAR XLI / 2017-Bahar / Arş. Gör. Dr. Aysel AHMADOVA

Sebin- 'sevinmek' - seb- 'sevmek': ...bodun ögürip, sebinip toktamış közü yögärü körti (Bilge Kağan Doğu 2) ' ...halk övünüp, sevinip, sakinleşmiş gözü yukarı baktı'.

Bu özellik çağdaş Türk dilleri için de geçerli (Ganiyev 2011: 647). Örneğin, körüs- 'görüşmek, selamlaşmak, el sıkışıp selamlaşmak' - kör'görmek', boluş- 'yardım etmek, başkasının işinde yer almak' - bol- 'olmak', keltür- 'getirmek' - kel- 'gelmek', kelis-, kileş-, kilis- 'anlaşmak, beğenmek, yararlı görünmek' - kel-, kil- 'gelmek' (Sravnitelno 1988: 270273); soklun- 'düşmek, kalmak' - sok- 'sokmak', alın- 'alınmak' - al- 'almak', bilin- 'pişman olmak' - bil- 'bilmek', kılın- 'hazırlanmak, gayret etmek' - kll- 'k1lmak', könük- 'tamamen yanmak' - kön- 'yanmak' (Gabain 1988: 59); ög- 'övmek' - ögir- 'sevinmek' (Kononov 1980: 173). Bu sözcüklerde çatı eklerinin çekim değil, yapım ekleri gibi davrandığı söylenebilir.

Fiil çatısına yakın olan diğer bir kategoriyse geçişli ve geçişsiz fiiller kategorisidir. N. K. Dmitriyev bu kategorinin çekim kategorisi olmadığı ve anlam açısından belirlendiğini yazar (Dmitriyev 1948: 180).

Çatı eklerinin sözcük yapımında kullanımı genelde bu eklerin sonradan kazandığı bir özellik olarak kabul görmüsstür: B. A. Serebrennikov (Sravnitelno 1988: 273), M. Erdal (Erdal 2004: 228). Ancak yapım eklerinin bu işleve daha ilk dönemlerden itibaren sahip olduğuyla ilgili bir kanı da Türkolojide kendine yer bulmuştur (Sravnitelno 1988: 273). Bunun sebebi olarak fiil çatısı ekleriyle yapılmış sözcüklerin Türk dilleri için daha eski olması ve bütün Türk dillerinin aitliği gösteriliyor (Sravnitelno 1988: 272). Ancak Eski Türkçede çatı kategorisinin daha sistematik oluşu ve çatı eklerinin anlam değişikliğine daha yol açması onların yapım eki özelliklerini daha sonradan kazandığını düşündürür.

Bazı dil bilimcilerin fiilimsi eklerini de ara ekler olarak sunmasına rağmen, bunlar çekim ekleridir çünkü bunlar anlam sınırlandırması olmaksızın bütün fiillere eklenebilmektedir. M. Erdem'in de söylediği üzere, araç, yön gösterme ve eşitlik ekleri fiilimsilere göre daha çok yapım ekidir (Erdem 2011: 85).

\section{Sonuç}

Türk dillerinde yapım ve çekim ekleri arasındaki ilişki uzun süre tartışma konusu olmuştur. Türkçede çekim eklerinin olmadığı, çekim amaçlı kullanılan eklerin işletme ya da yapı ekleri diye isimlendirilmesi gerektiğine dair görüşler de ortaya çıkmıştır (Demircan 1977: 98). Bu görüş Türk dillerindeki çekim eklerinin Batı dil bilimince belirlenen eklerden daha 
TÜBAR XLI / 2017-Bahar / Orhon Yazıtlarında Ara Ekler

farklı olması ile ilgilidir. Fakat bu fark Türk dillerinde çekim eklerinin tümüyle inkâr edilmesini gerektirmez, sadece onlara diğer dillerdekinden farklı çekim ekleri olarak bakılabilir.

Orhon yazıtlarında ara eklerin kullanımı şöyle özetlenebilir:

1. Ara ekler çekim eklerine nazaran yapım eklerine daha yakındır.

2. Ara ekler; isimlerden isim soylular, fiillerdense fiil yapar.

3. Ara ek alan isim soylu sözcükler tür değiştirmeğe eğilimlidir. Bu sözcükler genellikle isimleşme ve zarflaşmaya uğrar.

4. Bazı çatı ekleri yapım ekine daha yakındır. Bu olay çoğunlukla çatı ekleri alan fiil gövdelerinin anlamları ile ilgilidir.

\section{KAYNAKÇA}

ABDULLINA, G.R. (2008), "O razgraniçenii formaobrazuyuşix i slovoizmenitel'nıx kategoriy v başkirskom yazıke”, Vestnik Çelyabinskogo gosudarstvennogo universiteta, № 21, s.5-11.

BANGUOĞLU, Tahsin (1974), Türkçenin Grameri, Maha Matbaası, İstanbul.

BASKAKOV, N.A. (1952), Karakalpakskiy yazık. Tom II. Fonetika i morfologiya. Çast' I. Çasti reçi i slovoobrazovaniye, İzd-vo AN SSSR, Moskova.

BAŞDAŞ, Cahit (2006), “Türkçede Üçüncü Grup (Ara Ekler)”, I. Uluslararası Büyük Türk Dili Kurultayında Sunulan Bildiri, 26-27 Eylül 2006, Bilkent Üniversitesi, Ankara, http://turkoloji.cu.edu.tr/DILBILIM/cahit_basdas_ara_ekler.pdf.

(2011), “Türkçede eklerin hiyerarşisi ve ara ekler”, Seminerler, Muğla, http://turkoloji.cu.edu.tr/pdf/cahit_basdas_turkcede_eklerin_hiyerarsisi.pdf

BAUER, Laurie (2004), "The Function of Word-Formation and the Inflection-Derivation Distinction", Henk, Aertsen, Mike Hannay \& Rod Lyall (eds), Words in Their Places. A Festschrift for J.Lachlan Mackenzie, Vrije Universiteit, Amsterdam, pp. 283-292.

DEMİRCAN, Ömer (1977), Türkiye Türkiye Türkçesinde Kök-Ek Bileşmeleri, TDK Yay., Ankara.

DMITTRIYEV, N.K. (1940), Grammatika kumıkskogo yazıka, İzd-vo An SSSR, Moskva-Leningrad.

(1948), Grammatika bashkirskogo yazıka, İzd-vo An SSSR, Moskva-Leningrad. 
46

TÜBAR XLI / 2017-Bahar / Arş. Gör. Dr. Aysel AHMADOVA

ERDAL, Marcel (2004), A Grammar of Old Turkic, Brill, Leiden.

ERDEM, Mevlüt (2011), “Türkçede Çekim ve Yapım Eklerinin Özellikleri ve Sınurları", Bilig, say1: 58, s. 71-90.

ERGIN, Muharrem (1967), Türk Dil Bilgisi, Narodna Prosveta, Sofya.

GABAİN, A. von. (1988), Eski Türkçenin Grameri. Çeviren: M.Akalın, Türk Tarih Kurumu Basım Evi, Ankara.

GANIYEV, F. (2011), "Polifunktsional'nıye suffiksı v tatarskom yazıke", 38. ICANAS (Uluslararası Asya ve Kuzey Afrika Çalışmaları Kongresi). 10-15 eylül 2007. Bildiriler. Dil Bilimi, Dil Bilgisi Ve Dil Ĕgitimi, 1. Cilt, Ankara, s. 641-648.

GENCAN, Tahir N. (1979), Dilbilgisi, Ankara Üniversitesi Basımevi, Ankara.

GÜLSEVIN, Gürer (1997), Eski Anadolu Türkçesinde Ekler. Yükseöğretim Kurulu Matbaas1, Ankara.

(2004), "Türkçede Sıra Dıșı Ekler ve Eklerin Tasnif-Tanımlanma Sorunu Üzerine”, V. Uluslararası Türk Dili Kurultayı Bildirileri I, TDK Yay., Ankara, s. 1267-1283.

HABİÇEV, M. (1971), Karaçayevo-balkarskoye imennoye slovoobrazovaniye, Stavropolskoye knijnoye izdatelstvo, Çerkessk.

(1977), Karaçayevo-balkarskoye imennoye formoobrazovaniye i slovoizmeneniye, Stavropolskoye knijnoye izdatelstvo, Çerkessk.

HÜSEYNZADE, M. (2007), Müasir Azerbaycan Dili. III Hisse. Morfologiya. Şerq-Qerb, Bak1.

KARASOY, Yakup (2004), “Türkçede -ma (-me) Ekinin Yeri”, Türkiyat Araştırmaları Dergisi, Sayı 16, s. 1-14.

KONONOV, A.N. (1956), Grammatika sovremennogo turetskogo literaturnogo yazıka, İzdatelstvo Akademii Nauk SSSR, Moskva-Leningrad.

(1980), Grammatika yazıka tyurkskih runiçeskih pamyatnikov (VII-IX vv.), Nauka, Leningrad.

KİBRIK, Andrey A. (2005), "Inflection versus Derivation and the Template for Athabaskan Verb Morphology", S. Gessner (ed.), Proceedings of the 2005 Athabaskan Languages Conference, ANLC, Fairbanks, s. 67-94.

LEVSKOVSKAYA, K.A. (1952), “O slovoobrazovanii i ego otnoşenii k grammatike", Vopsorl istorii i teorii yazıka, Moskva, s. 153-182.

MíRZEZADE, H. (1990), Azerbaycan Dilinin Tarihi Grammatikası, Azerbaycan Universitesi Neşriyyatı, Bakı. 
TÜBAR XLI / 2017-Bahar / Orhon Yazıtlarında Ara Ekler

ORKUN, H.N. (1994), Eski Türk Yazıtları, Yükseköğretim Kurulu Matbaası, Ankara.

ÖZKAN, Nevzat (1996), Gagavuz Türkçesi Grameri, TDK Yay., Ankara.

POKROVSKAYA, L.A. (1964), Grammatika gagauzskogo yazıka. Fonetika $i$ morfologiya. Nauka, Moskva.

RASSADİN, V.İ. (2014), Sovremennıy tofalarskiy yazık $i$ ego mesto v sisteme tyurkskix yazıkov, İzd-vo Kalm. un-ta, Elista.

RECEBLİ, E. (2009), Qedim Türk Yazısı Abideleri, 4 cildde, I hisse, I cild, Nurlan, Bak1.

SEREBRENNIKOV, B.A., Gadjiyeva N.Z. (1979), Sravnitelno-istoriçeskaya gramatika tyurkskih yazıkov, Maarif, Baku.

SEVORTYAN, E.V. (1966), Affikst imennogo slovoobrazovanniya v azerbaydjanskom yazıke: opıt sravnitelnogo issledovaniya, Nauka, Moskva.

Sravnitelno-istoriçeskaya grammatika tyurkskix yazlkov. Morfologiya (1988), Nauka, Moskva.

ŞÇERBAK, A.M. (1977), Oçerki po Sravnitelnoy Morfologii Tyurkskih Yazıkov: imya. Nauka, Lenigrad.

TANRIVERDİ, E. (2012), Azerbaycan Dilinin Tarihi Grammatikası, Elm ve tehsil, Bak1.

TEKIN, T. (2003), Orhon Türkçesi Grameri, (Yay: Mehmet Ölmez), Türk Dili Araştırmaları 9, 2. Baskı, İstanbul.

TERES, Ersin (2013), “İli Salır Türkçesi’nde yapım ekleri”, Uluslararası Sosyal Araştırmalar Dergisi, Cilt: 6, Say1: 24, s. 332-347.

TURAN, Zikri (2007), "Türkçenin Yapım ve Çekim Düzeninde Yer Alan Eklerin Sınıflandırması Nasıl Olmalıdır?”, IV. Uluslararası Türk Dili Kurultayı Bildirileri-II 24-29 Eylül 2000, s.1835-1844, TDK Yay., Ankara.

ÜSTÜNER, Ahat (2001), "Eski Türkiye Türkçesinde -sUz Eki”, Fırat Üniversitesi Sosyel Bilimler Dergisi, Cilt: 11, Sayı: 2, s. 177-184.

ÜSTÜNOVA, Kerime ve HOROZ, Öznur (2001), “ $\{$-sİz $\},\{-1 \dot{I}\}$ ekinin olumsuzu mu?”, Eskişehir Osmangazi Üniversitesi Sosyal Bilimler Dergisi, Eskişehir, S. 1, s. 119-140.

ZEYNALOV, F. (2008), Türk dillerinin mügayiseli grammatikast. I hisse. Fonetik, leksika, morfologiya, "MBM” neşriyyatı, Bakı. 

